\author{
ESTHER JOHN PERRY ${ }^{1 \varpi}$, COLLIN JEROME $^{2}$ \\ ${ }^{1}$ Lecturer of Swinburne University of Technology, Sarawak Campus \\ (Malaysia, Sarawak, Kuching),e-mail: ejohnperry@swinburne.edu.my \\ ${ }^{2}$ Senior Lecturer of University Malaysia Sarawak \\ (Malaysia, Sarawak, Kuching), e-mail: jcollin@unimas.my \\ https://orcid.org/0000-0002-9205-8001
}

\title{
'A CURSE OR A BLESSING?': THE FATE OF IBAN WOMEN IN ‘ADAT NGUAI’ AS ILLUSTRATED BY LITERARY DEVICES IN IBAN SONG LYRICS
}

\begin{abstract}
Numerous studies have examined the depictions of men and women inIban songs. Such depictions revolve around the traditional roles of Iban men and women in both public and private domains. More studies, however, are needed to examine the nuances of these depictions, given the fact that many Iban popular songs portray gender in traditional Iban society. This paper aims to examine such nuances by exploring the fate of women in female Iban songs particularly on their rights and treatment by others as illustrated in the song lyrics. This study adopts the qualitative research design by using content analysis to analyze the description of Iban married women who decided to move out and live at their spouse home in two songs namely, 'Tusah Belaki Nguai' by Swaylin and 'Tusah Nyadi Menantu' by Linda Simai. The results show that the Iban women are 1) depicted as 'nguai' to her husband, who are submissive to the in laws and the husband, and 2) expected to display the quality of 'indu tampun puji' or 'menantu ke dipilih', that refers to the ideal concept of an Iban woman who is both hardworking and capable to manage the household.
\end{abstract}

Keywords: Iban songs, gender, popular songs, cultural studies, content analysis.

\author{
Эстер Джон Перри ${ }^{1}$, Коллин Джером² \\ ${ }^{1}$ Суинберн технологиялық университетінің оқытушысы, Саравак кампусы \\ (Малайзия, Саравак, Кучинг к.), e-mail: ejohnperry@swinburne.edu.my \\ ${ }^{2}$ Саравак Малайзия университетінің ава оқытушысы \\ (Малайзия, Саравак, Кучинг к..), е-mail: jcollin@unimas.my
}

\section{«Қарғыс па әлде бата ма?»: ибан халқының ән мәтіндеріндегі («Адат нгуай») әдеби құралдармен суреттелген ибан әйелдерінің тағдыры}

Андатпа. Ибан халқының әндеріндегі ерлер мен әйелдердің бейнелері көптеген зерттеулерде қарастырылады. Мұндай бейнелер ибандық ерлер мен әйелдердің мемлекеттік және жеке салалардағы дәстүрлі рөлдеріне қатысты. Алайда, көптеген танымал ибан әндері дәстүрлі ибан қоғамында гендерді бейнелейтінін ескерсек, осы суреттердің нюанстарын зерттеу үшін көп зерттеулер жүргізу қажет. Бұл мақаланың мақсаты - ибан әйел әндеріндегі

\footnotetext{
*Бізге дұрыс сілтеме жсасаңыз:

Esther John Perry, Collin Jerome 'A Curse or a Blessing?': the Fate of Iban Women in 'Adat Nguai' as Illustrated by Literary Devices in Iban Song Lyrics // Ясауи университетінің хабаршысы. - 2021. №4 (122). - Б. 20-26. https://doi.org/10.47526/2021-4/2664-0686.02

*Cite us correctly:

Esther John Perry, Collin Jerome 'A Curse or a Blessing?': the Fate of Iban Women in 'Adat Nguai' as Illustrated by Literary Devices in Iban Song Lyrics // Iasaui universitetinin habarshysy. - 2021. - №4 (122). - B. 20-26. https://doi.org/10.47526/2021-4/2664-0686.02
} 
әйелдердің тағдырын, әсіресе олардың құқықтары мен ән мәтінінде көрсетілгендей басқалармен қарым-қатынасын зерттеу арқылы осындай нюанстарды зерттеу. Бұл зерттеуде ерінің үйіне көшіп, сонда тұруға шешім қабылдаған тұрмыс құрған ибан әйелдерінің сипаттамасын талдау үшін екі әнге контент-талдау пайдалана отырып, сапалы зерттеу дизайны қолданылады. Атап айтқанда, Суэйлиннің «Туса Белаки Нгуай» және Линда Симайдың «Туса Ньяди Менанту» атты әндері. Нәтижелер Ибан әйелдерінің 1) туыстарына және күйеуіне бағынатын күйеуі үшін «нгуай» ретінде суреттелетінін және 2) олар бір мезгілде еңбекқор және үй шаруашылығын басқаруға қабілетті болып келетін ибан әйелінің идеалды тұжырымдамасына жататын «инду тампун пуджи» немесе «менанту ке дипилих» сапасын көрсетеді деп күтілетінін көрсетеді.

Кілт сөздер: ибан әндері, гендер, танымал әндер, мәдениеттану, контент-талдау.

\author{
Эстер Джон Перри ${ }^{1}$, Коллин Джером ${ }^{2}$ \\ ${ }^{I}$ преподаватель Технологического университета Суинберна, Кампус Саравака \\ (Малайзия, Саравак, г. Кучинг), e-mail: ejohnperry@swinburne.edu.my \\ ${ }^{2}$ стариий преподаватель Университета Малайзии Саравак \\ (Малайзия, Саравак, г. Кучинг), e-mail: jcollin@unimas.my
}

\title{
«Проклятие или благословение?»: судьба ибанских женщин в «Адат нгуай», иллюстрируемая литературными приемами в текстах ибанских песен
}

Аннотация. В многочисленных исследованиях изучались изображения мужчин и женщин в ибанских песнях. Такие изображения вращаются вокруг традиционных ролей ибанских мужчин и женщин как в государственных, так и в частных сферах. Однако необходимы дополнительные исследования для изучения нюансов этих изображений, учитывая тот факт, что многие популярные ибанские песни изображают гендер в традиционном ибанском обществе. Цель этой статьи - изучить такие нюансы, исследуя судьбу женщин в женских ибанских песнях, особенно в отношении их прав и обращения со стороны других, как показано в тексте песни. В этом исследовании используется качественный дизайн исследования с использованием контент-анализа для анализа описания замужних ибанских женщин, которые решили переехать и жить в доме своего супруга, в двух песнях, а именно «Туса Белаки Нгуай» Суэйлина и «Туса Ньяди Менанту» Линды Симаи. Результаты показывают, что женщины Ибана 1) изображаются как «нгуай» для своего мужа, которые подчиняются родственникам и мужу, и 2) ожидается, что они будут демонстрировать качество «инду тампун пуджи» или «менанту ке дипилих», что относится к идеальной концепции женщины Ибана, которая одновременно трудолюбива и способна вести домашнее хозяйство.

Ключевые слова: ибанские песни, гендер, популярные песни, культурология, контентанализ.

\section{Introduction}

Language has been the method for us to stay connected as we need a medium to convey and discuss ideas. Komorowska (cited in Siti Nursolihat \& Evie Kareviati, 2020) believes that language is an important tool that plays a major role in exchanging our ideas. Even the normal day-to-day conversation with other we often find it difficult to stay connected and find the true meaning of trying to figure out others' feelings and understand the thoughts of others. On a different level, the presence of figurative language has made it even more difficult for people to converse and achieve mutual understanding of the topics discussed. 
Iban music has been become the subject of people's interest in this changing times especially regarding issues relating to gender and identity. The issues surrounding the identify includes the traditional roles of Iban. With modernity and fast pace of development in Malaysia and the greater role of mass media, Iban songs are not easily accessed through online platforms such as Facebook, Tik Tok and YouTube. With the rapid advancement of technology and modernity, one of the issues concerned is the Iban women into modernity. The gender roles in modern society today might have not exist in the past. Some are relatively new trends in human society as social expectation of each gender change over time and developed differently in different cultures all around the world.

Even though some people may seem to fit within the specific categories of masculinity and femininity, there are some exceptions. The frequent misconception is when people believe that sex and gender are similar and therefore each sex has some expectations to meet. There are no questions to a great deal of progress that has been made towards gender equality despite the fact that it has not been fully achieved. In a traditional concept, often women are expected to have the quality of a motherly figure to be compassionate, caring, intuitive and poise. One of the concerns in this progression is the fate of women especially in the minority concept, in this case the Iban women in the setting of the $21^{\text {st }}$ century of modern Malaysia.

\section{Literature Review}

Literature is in face one of the greatest ways for humans to project their voices and feeling where it helps people to grown personally and intellectually (Arpentieva et al., 2021; Uteshkalieva \& Kumarova, 2021). Literature is considered as a valued art that not just entertainment. Literature in general is made up from collective individuals' experiences, emotions, and feelings. Van Peer (2020) describes the unique feature of literature as something that is abstract and has a major function in preserving culture. Lyrics and song lyrics are part of literature that involve people' feeling and mind. It is an expression of something that has been witnessed, herd and felt. Most people enjoy song lyrics without knowing where they come from. In a song, there will be some parts where the composer would integrate their lived through experience.

Figurative language in song lyrics

Figurative language can be found in different written work such as books, short stories, novels and even songs. It is often used to engage the readers and audience through a creative way to express your writing. It is associated as part of the semantic to help deciphering the true meaning in a song. Song has always been part of literature and Meyer (1997) defined it as written texts that are composed with careful of language. A song is one of the greatest forms of literature in which the composers or songwriters include their feelings, ideas, imaginations, and messages to listeners.

Often time, figurative language in songs can make reader understand the lyrics of the song and describe the message that can only be deciphered through a deeper understanding of the ideas portrayed in the lyrics. Listening to song is a fun activity and listeners can only get the joy if only they understand the figurative language in those songs. Even though a song has to be rhythmic, without the presence of poetic words, it would be less enjoyable for the listeners.

Music composers usually add artistic value to the lyrics with the intention to make immerse into their art and hidden messages. Often time, while listening to a song, an individual might only like the song due to its good music or because the singers are well-known to them (Siti Nursolihat \& Evie Kareviati, 2020). Knowing the meaning of song lyrics is equally important as it helps us to understand the meaning and the purpose of the song especially popular songs. The role of popular music is not something new and the primary meaning of popular music in the western context come from three approaches which are to link the scale of activity and the popularity of the songs through audience consumption. Song lyric is considered as an interesting part of a poetry and different that other literary work such as drama, film studies or prose. Song lyrics are often the products of expression of individuals' experience and feelings. Most song lyrics are using figurative language to aid their projection of ideas. 
Traditional Gender Roles and the concept of of 'nguai' in the Iban community

The 'adat nguai' in the Iban community

Historically, for the Ibans, the law or 'adat' is the way of encompassing life and to discourage conflict and safeguard the state of affairs in every aspect of the Iban community. Generally, the term 'adat' refers to the norms, a code of conduct that has been regarded as a medium to protect the relationship with other parts of the universe to preserve peace (Janang et. al, 2016, as cited in Chemaline anak Osop, 2017; Pertiwi et al., 2019).

In the traditional setting, the Iban were very particular about marriage as this 'adat nguai' is deemed as a very important issue when it comes to social and economic system of the Iban people. It is a practice to decide whether the woman is going to stay with her husband's family (nguai) or to stay with her own family (the opposite of nguai) upon agreement with both families. This practice originated from the folklore of a fair Iban Maiden named Lemiah who came from a good family and was admired by everyone in her village due to her capability to perform tremendous duty at home and paddy fields.

\section{Research methods}

This study used a qualitative research method. The data were from the lyrics of two songs Tusah Berlaki Nguai by Swaylin and Tusah Nyadi Menantu by Linda Simai. The lyrics were analysed and the researches attempted to find words, phrases and/or sentences that contained figurative language. Lastly, the researchers categorised the types of figurative languages found in the lyrics and drew the conclusion based on the analysis of the figurative languages used and also the entire context of the songs.

\section{Results}

'Tusah Belaki Nguai' is a song that was popularized by Swaylin in the late 2000s. Due to its popularity, there are many other versions of the song and have gained a collective amount of almost half a million view on YouTube. This song is composed by a male composer and inspired by the everyday life of a traditional Iban wife at a long house setting where she is occupied with household chores such as cooking, cleaning, and doing the laundry.

From the analysis, there are two types of figurative languages used in the song lyrics namely hyperbole and symbolism.

\section{Tusah Belaki Nguai}

Malu amai atiku sulu

Disindir indai nuan belama

Ngumbai aku enda patut ke menantu

Lalu ngumbai aku buruk gawa

Nyentuk ke aku bisi ninga

Indai nuan deka nyerara tua

Laban aku kenu ko ia

Baka langkau enda ngipak ke dampa

Enti aku berapi indai nuan sebana

Asi udah mansau dikumbai ya mata'

Ngumbai aku enda nemu nyumai

Laban teleba meli asi ba kedai

Ai mata ku labuh keberai

Ngenang penanggur penusah tua begulai

Pandak jak uku ngenang nuan

Nuan chukup mentas sereta meruan 
The symbolism found in this song is illustrated in Table 1 below.

Table 1 - Identification of figurative language in 'Tusah Belaki Nguai' by Swaylin

\begin{tabular}{llll}
\hline $\begin{array}{c}\text { No. } \\
\text { language }\end{array}$ & $\begin{array}{c}\text { Types of figurative } \\
\text { symbolism }\end{array}$ & \multicolumn{1}{c}{ Line } & \multicolumn{1}{c}{ Translated Meaning } \\
\hline 1 & $\begin{array}{l}\text { 8-Baka langkau enda } \\
\text { ngipak ke dampa }\end{array}$ & $\begin{array}{l}\text { This is a proverb in Iban language } \\
\text { which means is used to describe one's } \\
\text { incapability to be the match for } \\
\end{array}$ & \\
& & $\begin{array}{l}\text { another person due to his/her low } \\
\text { status. }\end{array}$ \\
\hline
\end{tabular}

The figurative language was found in Stanza 2, line 8. In this line, the figurative language comes from the mother-in-law to describe the singer (daughter in law) as someone that is not a match of her son due to her incapability to perform house chores. From the same stanza it was also found that that this is the main reason of the disapproval of the marriage. Even though the singer has been suffering from numerous humiliations and disapprovals from her in law, she believes that the husband is a good man, and the rejection only comes from her mother- in-law.

\section{Tusah Nyadi Menantu}

Chukup tusah idup berumah tangga

Enti tekena ke mentua pama

Diau ba rumah pan asai neraka

Pedis ati ninga jaku jaie belama

Enti ke kebun betanggui purun

Aku disindir seduai ia takut celum

Ngumbai aku sengaja minta puji

Dini endak ati ku sulu nyilu berari

Kasih meh aku tu ambai

Enti seduai ia endak ngubah perangai

Enti endak ketegal aku kasih ke anak

Anang nuan ngumbai singkang aku pandak

Nyamai aku pulai ari idup merinsa

Ngibun mentua kelalu pama

Enti di ajar seduai enggai mendiang

Aku nyau asai ke bejaku ngau dinding

Ari ke belaya manah ku diau aja

Laban aku enggai jaie ngau mentua

Kasih meh aku tu ambai

Enti seduai ia endak ngubah perangai

Enti endak ketegal aku kasih ke anak

Anang nuan ngumbai singkang aku pandak

Nyamai aku pulai ari idup merinsa

Ngibun mentua kelalu pama

Enti di ajar seduai enggai mending

Aku nyau asai ke bejaku ngau dinding

Ari ke belaya manah ku diau aja

Laban aku enggai jaie ngau mentua 


\begin{tabular}{|c|c|c|c|}
\hline No. & $\begin{array}{c}\text { Types of } \\
\text { figurative } \\
\text { language }\end{array}$ & Line & Translated meaning \\
\hline 1 & hyperbole & $\begin{array}{l}3 \text { - diau ba rumah pan asai } \\
\text { ba neraks }\end{array}$ & $\begin{array}{l}\text { The singers describes her as a } \\
\text { 'living hell' due to her endless } \\
\text { suffering as a daughter in law who } \\
\text { lives with her in laws. }\end{array}$ \\
\hline 2 & simile & $\begin{array}{l}26 \text { - Aku nyau asai ke } \\
\text { bejaku enggau dinding }\end{array}$ & \\
\hline
\end{tabular}

As can be seen from table 2 there are two figurative languages found in this song namely hyperbole and symbolism. In Stanza 1, the singer has started to lament her suffering and described her life as a 'living hell' due to the humiliation and difficulties that she is facing while living with her in laws. In the same stanza, she describes her in laws as proud people and are against their son's decision to make her the rightful daughter in law. In Stanza 6, the last stanza, the singer is using simile to describe her in laws who discredit her opinions and say in the family. Overall, the entire song is about rejection from her in laws due to her inability to meet up with the standard of the ideal daughter in law.

\section{Discussion}

This study has analyzed the lyrics from two songs that have had their place in the Iban community. Based on the findings and discussion earlier, the researchers concluded that the figurative languages found in the song lyrics are used to express their lamentation and fate living as the daughter in laws who do not meet the standard of the ideal women of choice. Symbolism is the dominant of the figurative language found in the song lyrics. The words used emphasis on their frustration of not being accepted by their in laws, especially the mother in law.

Furthermore, it is very profound in both songs that these two female singers want to emphasize on the conflict, misery, and their ill fate. The song told us how women who live with their in laws are struggling to be the ideal daughter in law and to be accepted by the new family she made through marriage. From the data in the findings, the researchers found that in both songs, the analysis shows that the Iban women are 1) depicted as 'nguai' to her husband, who are submissive to the in laws and the husband, and 2) expected to display the quality of 'indu tampun puji' or 'menantu ke dipilih', that refers to the ideal concept of an Iban woman who is both hardworking and capable to manage the household.

Both are not accepted due to their inability to perform chores that are normally expected to be fulfilled especially from the context of the traditional gender roles. Despite the societal pressure for change in our traditional gender roles, different factors such as cultures might still become a thing that worth our concerns.

\section{Conclusion}

This study is expected to be helpful to researchers, particularly in literary analysis and the gender roles of the Iban in the context of modern Malaysia. We need to ensure that married women are not prevented from having their rights to voice out their opinions and not to be mistreated in every way that they can. This can only be achieved by a significant way that society and individuals think about the gender roles and taking positive actions to move forward positively in line with the rapid urbanization context of the modern Malaysia.

If song lyrics are to provide clues to the life of a woman they have to be viewed overtime. Throughout the years, sound recordings and songs have presented us with various perspectives on 
the lives of women. Females are often portrayed as naïve, submissive creatures that need male protection and direction. Does this portrayal of women throughout the past few years of the modern Malaysia really portray their personal and social development?

To add, the data can also be used as a source to examine this topic further and expand the analysis from many different aspects and to incorporate listeners and composers in the triangulation of data. Many other aspects such educational background, personal and social change can be taken into consideration. Hopefully, this preliminary work will add light to this ongoing concern and debate concerning the gender roles of women, particularly in the Iban community.

\section{REFERENCES}

1. Arpentieva M.R.; Retnawati H.; Akhmetova T.A.; Azman M.N.A.; Kassymova G.K. (2021). Constructivist approach in pedagogical science. Challenges of Science. Issue IV, 2021, pp. 1217. https://doi.org/10.31643/2021.02

2. Chemaline anak Osop. (2017). Social Relation Between Gender (Sexes) in the Iban Longhouse Community. International Journal for Studies on Children, Women, Elderly And Disabled, 2 (June), 25-31.

3. Meyer, Jim. (1997). What Is Literature? A Definition Based on Prototypes. Work Papers of the Summer Institute of Linguistics, University of North Dakota Session. 41. 10.31356/silwp.vol41.03

4. Pertiwi, F.D., Sudrajat, A., Kumalasari, D., Retnawati, H., Waspada, S.P. Dossayeva, S.K., Kassymova, G.K., (2019). Gender equality in feminism. Bulletin the National academy of sciences of the Republic of Kazakhstan, 5(381), 112-121. https://doi.org/10.32014/2019.25181467.130

5. Siti Norsolihat \& Eva Kareviati. (2020). An Analysis of Figurative Language Used in the Lyric of "A Whole New World" By Zayn Malik And Zhavia Ward. Professional Journal of English Education, 3(4), 477-481.

6. Uteshkalieva A.; Kumarova Z. (2021). Organizational and managerial conditions for creating a health-saving environment of an educational organization. Challenges of Science. Issue IV, pp. 99-102. https://doi.org/10.31643/2021.015

7. Van Peer, W. (2020). But what is literature? Toward a descriptive definition of literature. In R. Carter \& P, Stockwell (Eds.), The Language and Literature Reader (pp. 118-126). Routledge. doi:10.4324/9781003060789-14 